\title{
Kernos
}

Revue internationale et pluridisciplinaire de religion grecque antique

32 | 2019

Varia

\section{Los oráculos en Heródoto. Tipología, estructura y función narrativa}

\section{Maurizio Giangiulio}

\section{Q OpenEdition \\ Journals}

Electronic version

URL: https://journals.openedition.org/kernos/3198

DOI: 10.4000/kernos.3198

ISSN: 2034-7871

\section{Publisher}

Centre international d'étude de la religion grecque antique

\section{Printed version}

Date of publication: 1 December 2019

Number of pages: $344-347$

ISBN: 978-2-87562-229-7

ISSN: 0776-3824

\section{Electronic reference}

Maurizio Giangiulio, "Los oráculos en Heródoto. Tipología, estructura y función narrativa", Kernos [Online], 32 | 2019, Online since 01 October 2019, connection on 02 February 2022. URL: http:// journals.openedition.org/kernos/3198 ; DOI: https://doi.org/10.4000/kernos.3198

This text was automatically generated on 2 February 2022.

Kernos 


\title{
Los oráculos en Heródoto. Tipología, estructura y función narrativa
}

\author{
Maurizio Giangiulio
}

\section{REFERENCES}

Carmen SÁNCHEZ MAÑAS, Los oráculos en Heródoto. Tipología, estructura y función narrativa, Zaragoza, Prensas de la Universidad de Zaragoza, 2018. 1 vol. $17 \times 23 \mathrm{~cm}, 422 \mathrm{p}$.

(Monografías de Filología Griega, 28). ISBN : 978-84-16935-08-6.

1 The book surveys all the passages in Herodotus' Stories whose content is related to oracular matters. It collects 101 'oracular passages' and aims to offer "an individual literary exploration for each one of them" (p. 15). All the relevant passages are grouped together by Types: 1. Military and political matters (49); 2. Private matters (16); 3. Ritual matters (14); 4. Colonial matters (12); 5. Guilt and expiation matters (10). These 5 sets of passages are investigated in chapters 1 to 5 , which constitute the main bulk of the volume (p. 39-374). The oracular passages are systematically analyzed with reference to a grid of 10 "categories" the Author (hereinafter 'A.') draws on the basis of both Fontenrose's book on the Delphic oracle (but also his "The Oracular Response as a Traditional Narrative Theme", Journal of Folklore Research 20-2/3 [1983], p. 113-120 would have been useful) and L.O. Juul, Oracular Tales in Pausanias, Odense, 2010. The 'categories' are the following: 1. context; 2. source (who refers the passage); 3. motive or occasion; 4. oracular site; 5 . questioner (i.e. the consultant); 6. question; 7. prophet; 8. oracular response; 9. formulation (indirect/prose or direct speech/verses); 10. outcome (reaction of the consultant[s], interpretation/explanation by the consultant[s], other characters or the narrator). Each one of the five chapters devoted to the scrutiny of the oracular passages is divided in two sections : the first includes passages providing detailed information regarding the above listed ten categories, while the second comments on those reports that do not mention the precise content of the oracular response, or simply relate the events in a vague fashion. 
2 The volume opens with an English abstract (8 p.), which is followed by an Introduction (p. 23-37), where scholarship on oracles in Herodotus is briefly, somehow perfunctorily, discussed, and the organization of the book is explained at length. Then follow the chapters where the oracular passages are classified and commented upon.

3 The conclusion of the work (Consideraciones finales, 375-398) expounds the distribution of the 'oracular events' and their types in the Stories, and goes through the main compositional and narrative aspects of the oracular passages the preceding chapters have looked at. As for distribution, the A. interestingly notes that 45 out of 101 passages do not report any oracular response, and/or do not provide any detailed information about their context, source, occasion, oracular site, consultant, question, prophet, formulation and outcome. Concerning the compositional aspects, the A. creates a sketchy - though not completely useless - typology of oracular interactions, with special reference to the relationship between the oracular voice and the consultants, and the interplay of consultation practices and responses. When it comes to the narrative aspects, the A. is aware of the fact that Herodotus uses oracular stories as a powerful and extraordinarily flexible narrative tool, but she limits herself to underlining how much the oracular passages contribute to delineate the characters involved in the narrative. Admittedly, the proposed seven narrative functions of the oracular passages (aetiology, legitimation, motivation, overdetermination of the events, proof or refutation, exploration or ethnographic description), instead of contributing to a deeper understanding of the meanings of the oracular narratives, oversimplify their complexities.

4 A rich Index Nominum at the end of the book (415-422) usefully lists the proper nouns that occur in the oracular passages discussed. A fourteen-pages final bibliography rounds out the monograph. It is rich and accurately compiled (but Bretschneider at p. 402 is the publishing house, not the editor of the volume), even though older secondary literature is neglected (for instance Benedict's De oraculis ab Herodoto commemorates, 1871, and Oeri's De Herodoto fonte Delphico, 1899 dissertations, not to mention the literature on the Cypselids and on Croesus). It must be noted, however, that the A. fails to acknowledge the studies on Delphic oracles by Luraghi, Giangiulio, Nafissi, Lupi, Vannicelli, Franchi, who have recently re-examined the "literary' Delphic oracles both on the occasion of the workshop "Verbum Dei. Oracoli e tradizioni cittadine nella Grecia antica" (held in Rome in 2011; see now SemRom n.S. III.2, 2014) and elsewhere.

5 At the end of the book the A. provides a Catalogue of all the oracular passages previously examined. The passages are listed, in the same order as they appear in the Histories, with numbers from 1 to 101, corresponding to their associated numbers in their treatment throughout the 5 chapters of the book (where numbers are in Roman figures). In the Catalogue every passage is also assigned to one of the 5 Types, as well as related to one of the 10 Categories, and partially translated.

6 The thorough survey of the oracular passages in Herodotus which is offered by the book aims to "accomplish an analytic examination of each oracle included in the Histories, with special attention to their internal structure and their relationships with the narrative context in which they feature" (p. 28). Although it is evident that such an approach is just the tip of the iceberg when it comes to comprehensively understand both oracular textuality and Herodotus' narrative as a whole, in recent years it has become more and more clear how important for Greek literary authors was to employ 
oracular stories as powerful narrative devices to convey complex meanings. Julia Kindt's recent book perceptively dwells on this issue and should have been attentively discussed by the A. The book under review does not enter the debate on how oracular stories/oracular tales can be properly defined and tends to take for granted that oracular stories simply account for a specific oracular event. Coherently, but after all misleadingly, each oracle is discussed separately (and often in different chapters), even in those cases in which it is abundantly clear that a compound (multi)oracular tale is at stake. To give just a few examples, among the stories and oracles related to Croesus in the Lydian logos, some are discussed in Chap. 1 (nos. 4-6 = PW 52-54), others in Chap. 2 (nos. 13-14 = PW 55-56); the oracles stories which scan the history of Cyrene until the fall of the Battiads are commented upon both in Chap. 1 (nos. 44-45 = PW 69-70) and in Chap. 4 (nos. 38-43 = PW 37-42); also the oracles for the Cypselids are treated separately from each other: the response prophesying to the Bacch(i)ads the birth of a strong lion (PW 7) is discussed in Chap. 1 (no. 60 p. 159-62), but the oracle to Eetion (PW 6) is considered much later (see Chap. 2, no. 59 p. 220-223), and so is the third one on the duration of the Cypselid dynasty (no.61 = PW 8). Similarly, the stories of Dorieus' adventures (see Chap. 1 p. 79-82 and Chap. 4 p. 331-333), of the king Leonidas and of many other leading figures are split in two (or more) parts. In addition to this, the close connections, in terms of content, lexicon, and style, between two (or more) oracles (e.g. those for Cypselus, and those concerned with Sparta, Tegea, and Orestes), are neglected. In light of the above, one is lead to think that the A. treats the single oracular episodes as if Herodotus had built his narrative around a number of oracular 'fragments' that he had happened to come across.

On a more general level, the deliberate choice by the A. of avoiding any analysis of the larger narrative units in which the oracular episodes play a role (as is the case of the Croesus logos, the colonization tales, or the stories about kings, tyrants and politicians, not to speak of the stories about Xerxes' invasion of Greece) has at least two serious drawbacks. On the one hand it makes it almost impossible to ascertain whether the oracular responses are texts which have been introduced within an already existent narrative context, or, according to an opposite view, the oracular stories are framing narratives which came to incorporate - and to conform to - oracles that had already been in circulation. On the other hand, A.'s choice surely does not help to map those correspondences, at the level of both text and content, between the responses and the oracular stories, which should lead us to assume that the oracles cannot have taken shape outside the narrative. In other words, the approach taken by the A. makes it impossible to understand when and how the oracles and the stories were shaped, reciprocally and in parallel, giving birth to what deserves to be effectively defined 'oracular tales' par excellence.

8 Even more importantly, the approach taken by the A. hinders wondering whether Herodotus' oracular stories did already have a textual structure before Herodotus: in other terms, whether Herodotus could draw on a pre-existing "oracular tradition". As Marie Delcourt maintained, in a seminal book which the A. neglects (L'Oracle de Delphes, Paris, $\left.1955\left[1981^{2}\right]\right)$, all of the oracles in Herodotus belong to an age well before his life. In addition to all this, it would be necessary to systematically investigate to what extent the oracle stories that appear to have developed in accordance with the structural logic of the narratives, actually were traditions which could be ascribed to political communities, or groups within those communities, or powerful political figures. In other words, the key question is whether and to what extent stories that hinge on 
predictive oracles were intrinsic elements of the cultural identity and the image of the past belonging to specific groups and local communities. An investigation of the oracular episodes playing a narrative function within the stories in which they are embedded would be the kind of research that allows to assess the gap between the meaning of the oracular stories within local knowledge and the meaning Herodotus attributes to them within the semantic framework of the Stories. Such a research could contribute both to the comprehension of Archaic social memory and of Herodotus' historiography.

9 The A. of Los oráculos en Heródoto does not set herself the goal of studying the complexities of archaic 'oracular tradition', and only occasionally her research transcends mere descriptive and typological aims. At any rate, the book deserves to become part of the toolbox that whoever wants to start looking into oracles in Herodotus' Stories should have at his disposal.

\section{AUTHORS}

\section{MAURIZIO GIANGIULIO}

Trento University I 